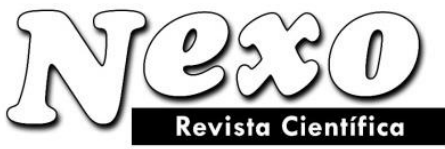

ISSN-E 1995-9516

Universidad Nacional de Ingeniería COPYRIGHT @ (UNI). TODOS LOS DERECHOS RESERVADOS http://revistas.uni.edu.ni/index.php/Nexo https://doi.org/10.5377/nexo.v34i06.13169

Vol. 36, No. 06, pp. 1819-1825/Diciembre 2021

(c) (i) $(5)$

\title{
Improvement of the traction current asymmetry control system
}

\section{Mejora del sistema de control de asimetría de corriente de tracción}

\author{
Maksim V. Basharkin*, Alevtina G. Isaycheva, Valery B. Teplyakov \\ Samara State Transport University, Samara, Russia \\ *email: $\underline{\text { m.v.basharkin@yandex.ru }}$
}

(recibido/received: 18-octubre-2021; aceptado/accepted: 02-diciembre-2021)

\begin{abstract}
The article presents approaches that allow modernizing the system for monitoring the asymmetry of the traction current. The existing systems of technical diagnostics and monitoring of the technical condition of automation and telemetry control devices, which have found wide application on the railways of JSC Russian Railways, do not allow monitoring the condition of adjacent railway transport infrastructure systems that affect the performance of railway automation and telemetry control devices. Besides, information about the condition of the object being diagnosed is sent to the monitoring center, while the operational and repair personnel do not have the necessary information and start working only after receiving information about the malfunction from the dispatcher of the monitoring center. The mobile device, proposed in the article, allows reducing the time necessary for obtaining information about the unserviceable condition of the railroad line. The article presents the analysis of gadgets planned for use in a mobile device, and the concept of the interface of the mobile application for technicians. It is noted that the hardware intended for use in a mobile device must provide protection against unauthorized access to the application, as well as have a high degree of protection against penetration. Besides, the article identifies the areas for further improvement of the traction current asymmetry control system.
\end{abstract}

Keywords: asymmetry coefficient; diagnostics; mobile device; monitoring; traction current asymmetry, traction rail network.

\section{RESUMEN}

El artículo presenta enfoques que permiten modernizar el sistema de seguimiento de la asimetría de la corriente de tracción. Los sistemas existentes de diagnóstico técnico y monitoreo del estado técnico de los dispositivos de control de automatización y telemetría, que han encontrado una amplia aplicación en los ferrocarriles de JSC Russian Railways, no permiten monitorear el estado de los sistemas de infraestructura de transporte ferroviario adyacentes que afectan el desempeño del ferrocarril. dispositivos de control de automatización y telemetría. Además, la información sobre el estado del objeto que se está diagnosticando se envía al centro de monitoreo, mientras que el personal operativo y de reparación no tiene la información necesaria y comienza a trabajar solo después de recibir información sobre el mal funcionamiento del despachador del centro de monitoreo. El dispositivo móvil, propuesto en el artículo, permite reducir el tiempo necesario para obtener información sobre el estado inservible de la línea del ferrocarril. El artículo presenta el análisis de los gadgets previstos para su uso en un dispositivo móvil y el concepto de la interfaz de la aplicación móvil para técnicos. Cabe señalar que el hardware destinado a ser 
utilizado en un dispositivo móvil debe proporcionar protección contra el acceso no autorizado a la aplicación, así como tener un alto grado de protección contra la penetración. Además, el artículo identifica las áreas de mejora adicional del sistema de control de asimetría de la corriente de tracción.

Palabras claves: coeficiente de asimetría; diagnósticos; dispositivo móvil; vigilancia; asimetría de corriente de tracción, red ferroviaria de tracción.

\section{INTRODUCTION}

Since 1997, the railway network has been actively implementing a system of technical diagnostics and monitoring based on the collection and processing of information about the condition of trackside and station devices (Efanov, et al. 2019). The main task of technical diagnostics and monitoring systems is to improve maintenance and minimize the number of employees.

An innovative approach to optimizing maintenance has made it possible to reduce staffing positions at signaling, centralization, and blocking railways divisions. However, with an increase in the volume of diagnostic information, the decision-making process for further actions has become more complicated, especially in emergencies. Therefore, technical diagnostics and monitoring systems are supplemented with additional algorithms and predictive analytics functions. Within the framework of the digital transformation concept of transport, an approach to the organization of maintenance using mobile devices is possible, which can be used not only to improve technological discipline but also to obtain diagnostic information over time when working with this device, including in the field conditions (Nassonov, 2019).

\section{METHODS}

The operation of the traction current asymmetry control system is ensured by the synchronous and uninterrupted operation of three levels.

The upper level includes a server, where information is processed based on Big Data technology, as well as automated workstations of engineers and dispatchers of the monitoring center, and a mobile device of a technician.

The middle level includes hubs collecting information from measuring controllers, located at railroad sections and stations, as well as transmitting the received data to the server.

The lower level consists of measuring channels (controllers) that provide measuring the traction current in the rail line, as well as calculate the asymmetry coefficient of (Figure 1).

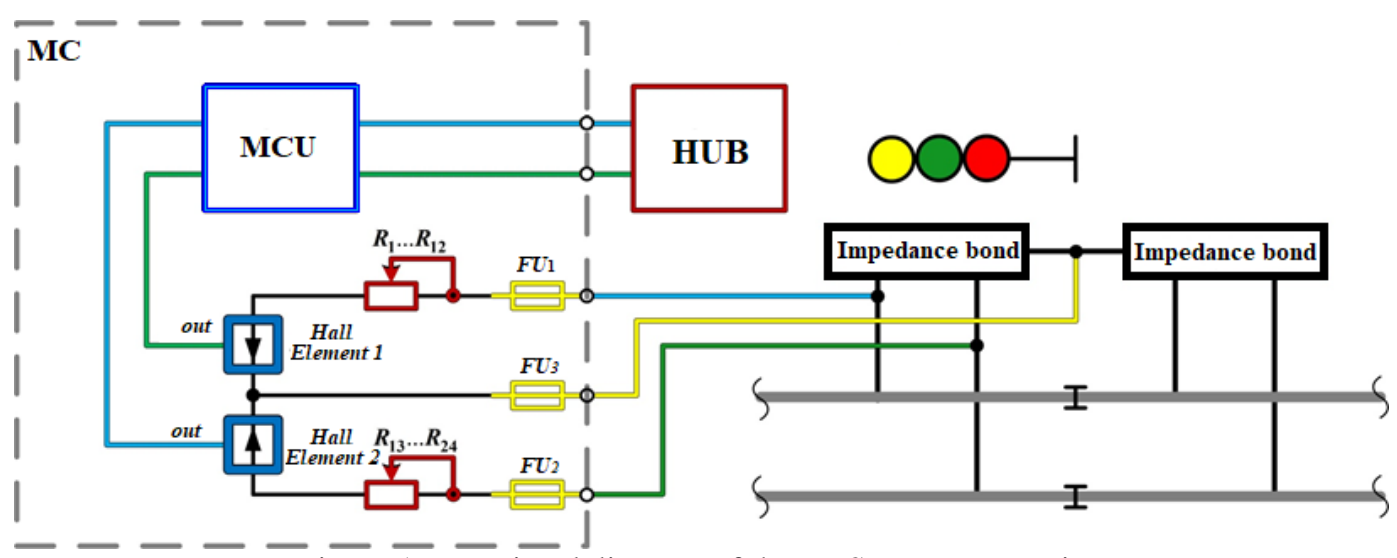

Figure 1. Functional diagram of the IR-STDM connection 
We developed measuring channels that allow monitoring the traction current asymmetry in a rail line both on electrified sections of direct current railways (MC-STDM-1S, MC-STDM-1B) and those of alternating current (MC-STDM-2S, MC-STDM-2B). Moreover, the control can be carried out at stations and railroad sections (Isaycheva, et al. 2020).

The traction current measurement is carried out by using $R_{s}$ resistors, whose nominal resistance to direct current (DC) is 999 times greater than the resistance $R_{i b}$ of the half-windings of choke transformers. Thus, the current flowing through the shunt $\left(I_{\mathrm{s}}\right)$ can be calculated by the formula:

$$
I_{s}=I_{i b} \cdot \frac{R_{S}}{R_{S}+R_{i b}}=I_{i b} \cdot \frac{R_{S}}{1000 R_{S}}=I_{i b} \cdot 10^{-3}
$$

The estimated values of the shunt resistances $R_{s}$, used in the device when connected to choke transformers of various types, installed on electrified sections of DC railways are shown in Table 1.

Table 1. The shunt resistance value $R_{s}$ for various types of choke transformers of the Rs (Ohms)

\begin{tabular}{cc}
\hline Type of choke-transformer & Shunt resistance $R_{\mathrm{S}}(\mathrm{Ohm})$ \\
\hline DT-0.2-500 & 1.4 \\
DT $-0.6-500$ & 2.4 \\
DT $-0.2-1000$ & 0.8 \\
DT $-0.6-1000$ & 1.1 \\
DT $-0.2-1500$ & 0.5 \\
DT -0.4-1500 & 0.8 \\
\hline
\end{tabular}

The analog signal from the sensors, containing information about the traction current value, enters the microcontroller, where the signal is processed and the asymmetry coefficient is calculated. The asymmetry coefficient is determined by the formula:

$$
K_{a}=\frac{\left|I_{s 1}-I_{s 2}\right|}{I_{s 1}+I_{s 2}} \cdot 100 \%
$$

where $I_{\mathrm{s} 1}$ is the traction current, flowing through the shunt, connected to the first semi-winding of the choke transformer $(\mathrm{A}), I_{\mathrm{s} 2}$ is the traction current flowing through the shunt, connected to the second semiwinding of the choke-transformer (A).

The actual values of the traction current in the first $I_{1}$ and second $I_{2}$ track rails are calculated according to the following formulas:

$$
\begin{aligned}
& I_{1}=I_{\mathrm{s} 1} \cdot 10^{3}, \\
& I_{2}=I_{\mathrm{s} 2} \cdot 10^{3} .
\end{aligned}
$$

The received data are transmitted via the RS-485 interface to the hub and further to the server, from where the information, collected from all measuring channels of the controlled section is sent to the dispatcher's monitor, as well as to the mobile device of the technician (Figure 2) (Kolodenkova y Dolgiy, 2018; Mascardi, et al. 2009). 


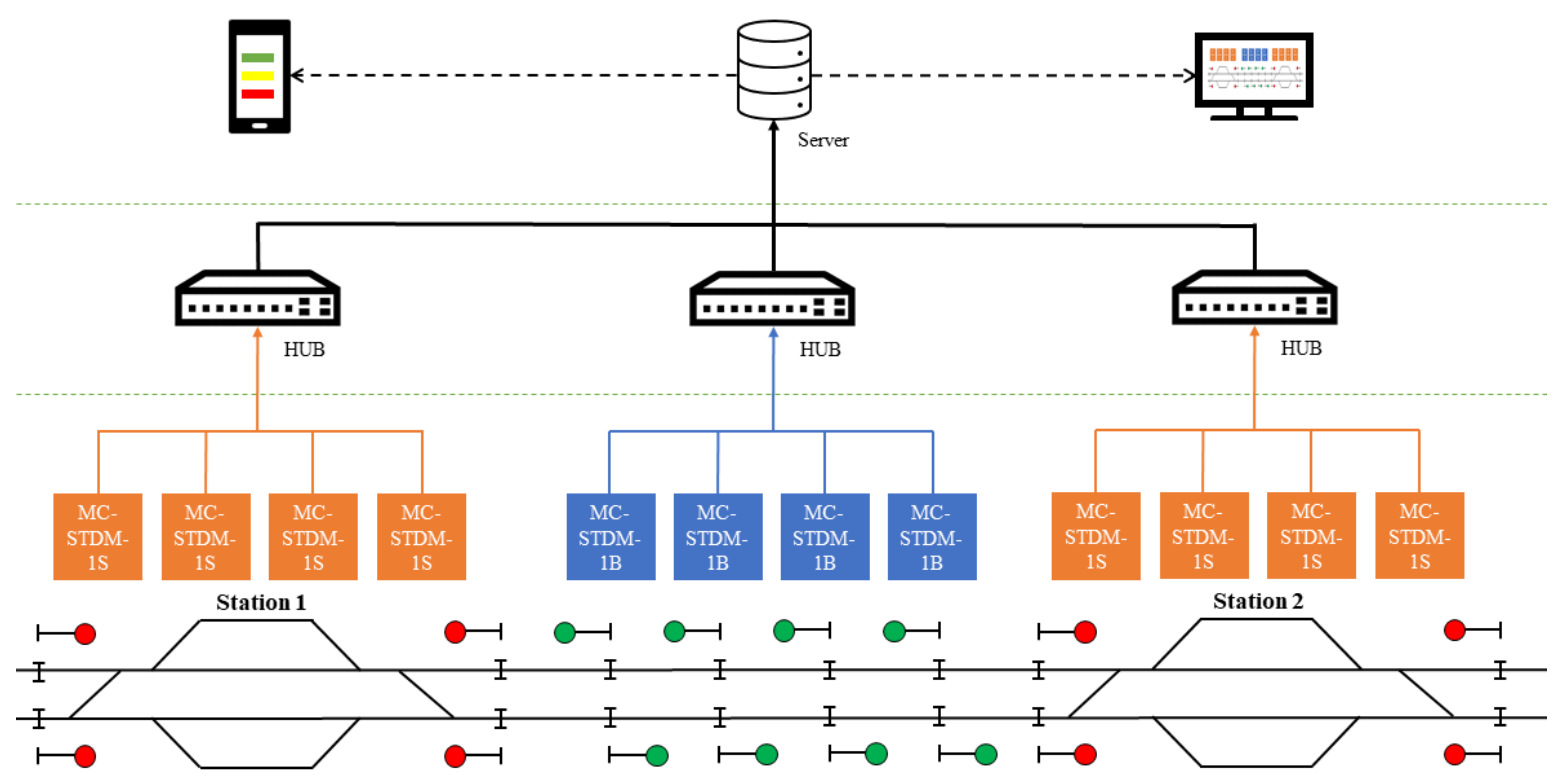

Figure 2. Block diagram of the traction current asymmetry control system in a rail line

It is worth noting that in the existing systems of technical diagnostics and monitoring, currently used in railway transport, in particular, in automation and telemetry control devices, information about the condition of devices is received only on the screen of the dispatcher of the monitoring center. At that, its operational transfer to a technician is quite problematic. In the proposed system, this disadvantage is solved by providing access to information through a personal mobile device, where data is displayed in real-time (Jian, et al. 2019).

\section{RESULTS. Development of a mobile device}

\subsection{Mobile device hardware}

The gadget used in a mobile device must meet the requirements of reliability and security. Mobile Inform Group has developed the MIG C55 smartphone, which operates based on the Avrora operating system (Mobile Inform Group, 2021). It supports GPS, GLONASS, BeiDou, and Galileo navigation systems, as well as 3G/4G/LTE, WiFi $802.11 \mathrm{a} / \mathrm{b} / \mathrm{g} / \mathrm{h} / \mathrm{ac}$, BLE wireless communication standards. The device is equipped with dust and moisture protection meeting IP67 standards and can withstand falls from a height of $1.2 \mathrm{~m}$ on a concrete floor. An autonomous operation time of the device is up to 22 hours at a temperature of $20^{\circ} \mathrm{C}$. Information protection is provided by built-in cryptography tools. These characteristics allow using the smartphone in the field conditions during the whole working day. The mobile device can also be placed based on the R-Style produced FRMD101A smartphone, which has characteristics, similar to the MIG C55 but has not been widely distributed on the railway network of JSC Russian Railways (AlexeyNadezhin, 2013).

It should be noted that using a smartphone in a mobile device allows obtaining data on the asymmetry coefficient, as well as the magnitude of the traction current in the rail line. However, it does not guarantee an instant response of the operational and repair personnel in the event of a malfunction. To minimize the time of receiving information about the appearance of a pre-failure condition, it is proposed to use a bracelet with a vibration function. The vibration signal carries information that a malfunction has occurred, and the technician needs to open the mobile application as soon as possible to get information about the place of its occurrence.

\subsection{Application Interface}


The mobile application should contain information about the traction currents magnitudes and asymmetry coefficients at the site located in the service area of the technician. At that, information about the condition of adjacent sections will be redundant. This task is solved by the personalization of mobile devices and their identification in the database, which will allow the server to send only the necessary information. Figure 3 shows the interface of the mobile application for the technician.

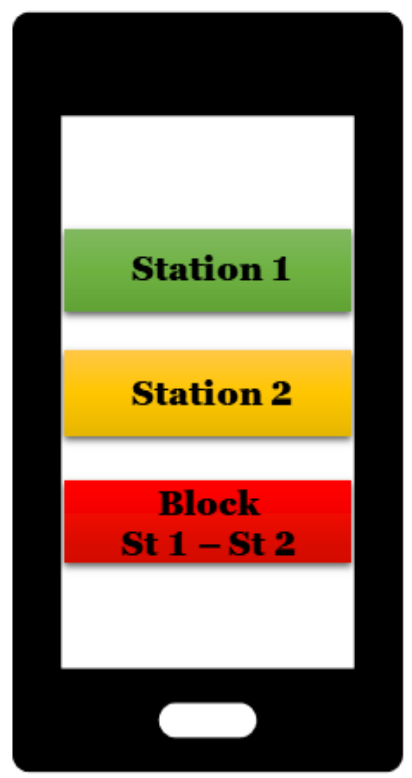

$a$

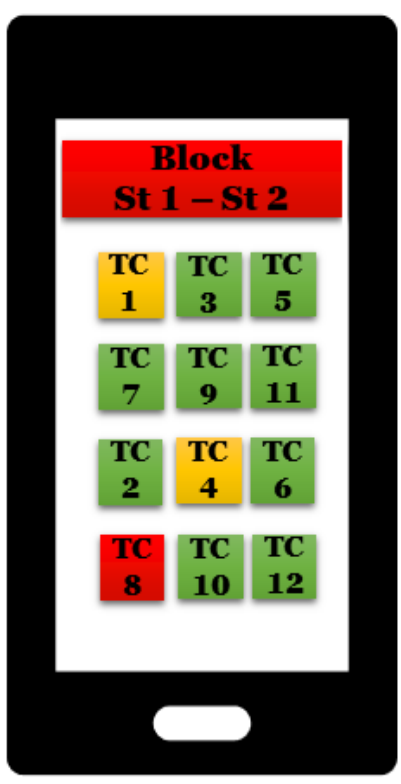

$b$

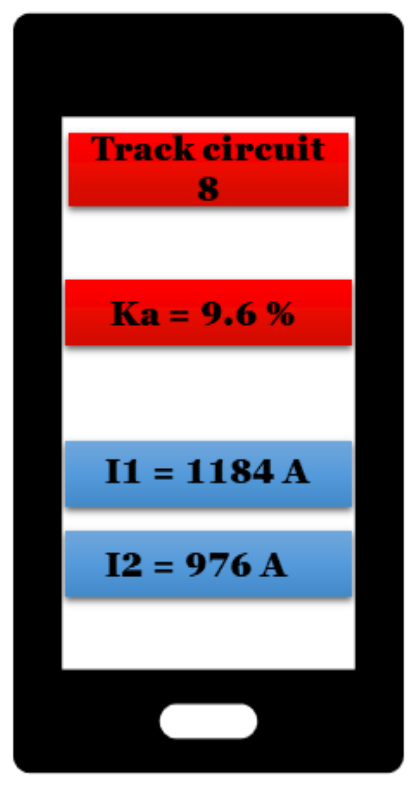

$c$

Figure 3. The interface of the mobile application for technician

The main screen of the application (a) displays stations and railroad sections are displayed, as well as their current status. The green color indication corresponds to the areas where the asymmetry coefficient is normal. When the asymmetry coefficient is 3.5-4\% at AC electric railways and 5.5-6\% at DC electric railways within at least one rail circuit, the station (railroad section) cell becomes yellow, which corresponds to the pre-failure condition. The red color indicates that the permissible value of the asymmetry coefficient has been exceeded (more than $4 \%$ for AC electric current, and more than $6 \%$ for DC electric current).

When opening the menu of section $(b)$, the technician sees its actual state. In the case presented in Figure 3 , the asymmetry coefficient of the traction current within the boundaries of the rail chain 8 exceeds the standard value, which is why the cell of the considered rail chain and the railroad section on which it is located is displayed in red. To find out the value of the traction currents and the asymmetry coefficient, the technician should select the concerned rail circuit, after which he should switch to the menu $(c)$.

Thus, the technician can assess the current situation and take the necessary measures.

\section{DISCUSSION}

In the course of the work, a configuration of the traction current asymmetry control system is proposed, which includes three main levels.

It is determined that using a personal mobile device will allow the technician to get the information required to monitor the condition of the serviced area, and will reduce the time required to obtain information about the malfunction. 
The concept of the application interface has been developed, whose essence is the color-based division of sections: green corresponds to stations (railroad sections) where the asymmetry coefficient corresponds to the standard value, yellow corresponds to areas with a detected pre-failure condition, and red indicates that the standard value of the asymmetry coefficient is exceeded.

Further research on the concerned topic can be carried out in several areas:

- developing measuring controllers and sensors that allow measuring the traction current to determine its harmonic spectrum and detect interfering interference;

- $\quad$ creating measurement and computing systems that would provide predictive analytics of the traction rail network condition;

implementing solutions that will allow transferring information from the server to a mobile device not only at Internet access points but also in places with a low signal level.

\section{CONCLUSION}

The traction current asymmetry monitoring system in the rail line allows monitoring the traction current asymmetry coefficient and predicting faulty states.

The system becomes particularly relevant in the context of heavy train traffic when the traction current can exceed 3,000 A, while the asymmetry coefficient of the traction current that does not correspond to the normative values, can cause train downtime, which will negatively affect the image and financial condition of the carrier company (Shamanov y Pultyakov y Trofimov, 2020).

\section{REFERENCES}

Efanov, D.V., Osadchy, G.V., Khroshev, V.V, Shestovitskiy, D.A. (2019). Diagnostics of AudioFrequency Track Circuits in Continuous Monitoring Systems for Remote Control Devices: Some Aspects IEEE East-West Design \& Test Symposium (EWDTS), pp. 162-170. DOI: 10.1109/EWDTS.2019.8884416

Nassonov, G.F. (2019). Digital infrastructure transformation. Automation, Communication and Informatics, 4, 2-4.

Isaycheva, A.G., Volik, V.G., Basharkin, M.V., Mitrofanov, A.N. (2020). Method of controlling asymmetry of traction currents in the rail line. Bulletin of the Volga Region Transport (Vestnik Transporta Povolzhya), 83(5), 29-34.

Kolodenkova, A.E., Dolgiy, A.I. (2018). Diagnosing of devices of railway automatic equipment based on methods of diverse data fusion. Advances in Intelligent Systems and Computing, 875, 277-283.

Mascardi, V., Briola, D., Martelli, M., Caccia, R., Milani, C. (2009). Monitoring and diagnosing railway signaling with logic-based distributed agents. Springer, Heidelberg, 53, 108-115. DOI: 10.1007/978-3-540-88181-0_14 
Jian, C., Suwen, W., Xiaoping, X., Shaquing, Z. (2019). Environmental monitoring system based on IOT android platform. IOP Conf. Ser.: Earth Env., 467, 012129

Mobile Inform Group (2021). Zashchishchonnyy smartfon MIG C55 Avrora [Rugged smartphone MIG C55 Aurora]. Available at: http://web.archive.org/web/20210116062057/https://minfogroup.ru/oborudovanie/promyshlennye-smartfony/775-mig-c55

AlexeyNadezhin. (2013). Smartfon ot RZHD: rasstavlyayem tochki nad I [Smartphone from Russian Railways: dotting the i]. Available at: https://habr.com/ru/company/boxowerview/blog/202698

Shamanov, V.I., Pultyakov, A.V., Trofimov, Yu.A. (2020). Main electromagnetic jammer sources with impact on the railroad automation systems. IOP Conf. Ser.: J. Phys. 1661, 012012 